\title{
Anonymous source usage in traditional and public journalism during 2004 election campaign: A content analysis study
}

Jayendran Srinivasan

West Virginia University

Follow this and additional works at: https://researchrepository.wvu.edu/etd

\section{Recommended Citation}

Srinivasan, Jayendran, "Anonymous source usage in traditional and public journalism during 2004 election campaign: A content analysis study" (2006). Graduate Theses, Dissertations, and Problem Reports. 3239. https://researchrepository.wvu.edu/etd/3239

This Thesis is protected by copyright and/or related rights. It has been brought to you by the The Research Repository @ WVU with permission from the rights-holder(s). You are free to use this Thesis in any way that is permitted by the copyright and related rights legislation that applies to your use. For other uses you must obtain permission from the rights-holder(s) directly, unless additional rights are indicated by a Creative Commons license in the record and/ or on the work itself. This Thesis has been accepted for inclusion in WVU Graduate Theses, Dissertations, and Problem Reports collection by an authorized administrator of The Research Repository @ WVU. For more information, please contact researchrepository@mail.wvu.edu. 


\title{
Anonymous Source Usage in Traditional and Public Journalism during 2004 Election Campaign: A Content Analysis Study
}

\author{
Jayendran Srinivasan
}

\author{
A Thesis submitted to the \\ Perley Isaac Reed School of Journalism \\ at West Virginia University \\ in partial fulfillment of the requirements \\ for the degree of \\ Master of Science \\ in \\ Journalism \\ Ivan Pinnell, Ph.D., \\ George Esper, Ph.D., \\ Brian Patterson, Ph.D., \\ Bonnie Stewart, MA
}

Perley Isaac Reed School of Journalism

Morgantown, 2006

Key Words: Anonymous Sources, Public Journalism, 2004 Presidential Elections 


\title{
ABSTRACT \\ Anonymous Source Usage in Traditional and Public Journalism during 2004 Election Campaign: A Content Analysis Study
}

\section{Jayendran Srinivasan}

\begin{abstract}
Anonymous source usage has been a much debated topic in mass communication circles ever since the Watergate scandal. This study examines the use of anonymous sources in traditional and public journalism newspapers during the 2004 Presidential campaign. A content analysis was done on four newspapers - two traditional journalism and two public journalism papers - from two states, West Virginia and Ohio, both swing states during the election. Every article written by a staff writer on George Bush, John Kerry, Dick Cheney and John Edwards from June 1, 2004 to November 2, 2004 was analyzed for anonymous source usage. The results of the study indicate that traditional journalism newspapers use significantly more anonymous sources and attributions but it also shows that both traditional and public journalism use very few anonymous quotes.
\end{abstract}




\section{Acknowledgment}

I would like to thank God for providing me this opportunity to complete this thesis. I would like to thank Dr. Ivan Pinnell, who has been a special advisor and an immense help throughout my Master’s program. I would also like to thank Dr. Terry Wimmer, Dr.Brian Patterson, Dr. George Esper for assisting me with my thesis and course work. And finally, my sincere thanks to Dr. James Smith who encouraged me to complete my thesis. 


\section{TABLE OF CONTENTS}

ABSTRACT .....................................................................

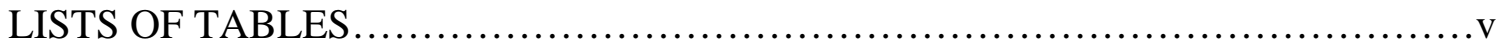

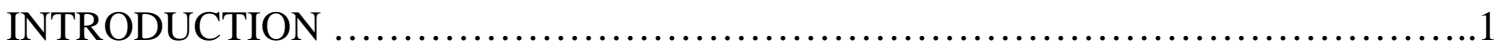

LITERATURE REVIEW ......................................................

Anonymous Sources: Opinions of Supporters and Critics

Research Findings on the Use of Anonymous Sources

Opinion of Readers

Policies Involving Use of Anonymous Sources

Public Journalism

Opinions For and Against Public Journalism

Case Studies Involving Public Journalism

Research Findings on Public Journalism

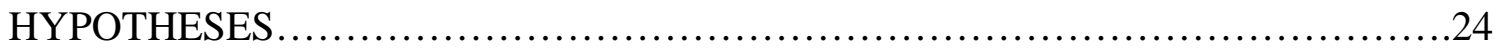

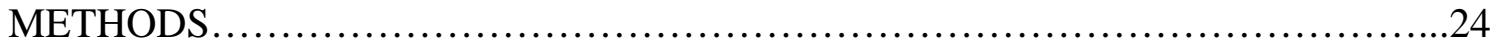

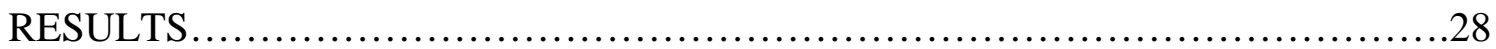

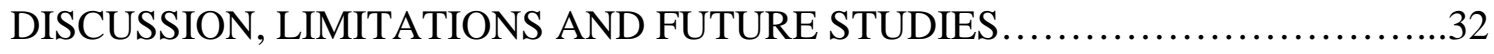

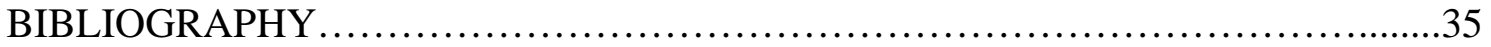

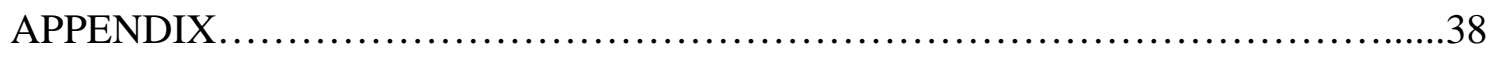




\section{LIST OF TABLES}

Table

Page

1. Summary of Anonymous Source Usage Data 28

2. Breakdown of Anonymous Source Usage Data for Each Newspaper 29

3. Table 3:Chi-Square Test to Check Hypothesis 1

4. Table 4: Chi-Square Test to Check Hypothesis 2 


\section{$\underline{\text { Introduction }}$}

Anonymous source usage has been a much debated topic in mass communication circles ever since the Watergate scandal. Editors, newsroom policies, journalism text books are virtually unanimous in their verdict: Attribute important information in news stories. ${ }^{1}$ Yet network newscasts, newsmagazines, and newspapers use unnamed sources with regularity. ${ }^{2}$ The information source is crucial to understanding the meaning and significance of the message. ${ }^{3}$ Even though each news outlet has its own sourcing policy about the use of anonymous attribution, the sourcing policies have never been standardized for all news media. ${ }^{4}$ In fact, American journalists have been relying on unnamed sources for more than a century. ${ }^{5}$

Over the last 15 years, some newspapers in the country are embracing a new form of journalism called public or civic journalism - where newspaper organizations become more involved in community affairs and take leadership roles in community organizations and even stimulate community examination of local needs by sponsoring forums of public discourse.

According to Philip Meyer, "traditional journalism emphasizes the values of fairness, balance and detachment, which in turn establishes newspapers’ credibility

\footnotetext{
${ }^{1}$ David E. Boeyink, “Anonymous Sources in News Stories: Justifying Exceptions and Limiting Abuses,” Journal of Mass Media Ethics 5, no.4 (1990): 233.

${ }^{2}$ Ibid.

${ }^{3}$ Ibid.

${ }^{4}$ Steven A. Esposito, “Anonymous White House Sources: How They Helped Shape Television News Coverage of the Bill Clinton- Monica Lewinsky Investigation,” Communications and the Law 21, no. 3 (September 1999): 2.

${ }^{5}$ Bruce W. Sanford and Anne R. Noble, “Threats Escalate to Strip Confidential Sources from Reporter’s Tool Kit,” Quill (April 1992): 10-11.
} 
among the readers and by extension, creates a market among advertisers who want their products and services featured in a credible medium." ${ }^{6}$ But "public journalism pulls back from detachment. It casts the press in a more active role of presenting information to the readers to motivate community action in order to solve problems and of creating the forum for citizens to become politically active.”7

Jay Rosen, a New York University professor and a strong advocate for public journalism, defined public journalism as an approach to the daily business of the craft that calls on journalists to address people as citizens, potential participants in public affairs, rather than victims or spectators, help the political community act upon, rather than just learn about its problems; improve the climate of public discussion, rather than simply watch it deteriorate; and help public life go well, so that it earns its claim on our attention. Public journalism tries to address this question: What does it take to make the democracy work and what should be asked of the press? ${ }^{8}$

Most of the research on anonymous sources has been focused on organizations that follow traditional journalism. Therefore the following research question was asked: Do traditional journalism papers use greater anonymous sources compared to public journalism papers?

\footnotetext{
${ }^{6}$ David M. Arant and Philip Meyer, "Public Journalism and Traditional Journalism: A Shift in Values,” Journal of Mass Media Ethics 13, no.4 (1998): 205

${ }^{7}$ Ibid.

${ }^{8}$ Jay Rosen, What are Journalists for? (New Haven and London: Yale University Press, 1999), 21.
} 


\section{Literature Review}

\section{Anonymous Sources: Opinions of Supporters and Critics}

The problem with anonymous attribution is that it can be both beneficial and

detrimental. ${ }^{9}$ It can be a beneficial journalistic tool when the practice is used carefully and cautiously with rigorous controls. But when the practice is used arbitrarily without proper controls, it can weaken the use of known sources. ${ }^{10}$

Journalists view the use of anonymous sources with mixed feelings. This ambivalent feeling was best summed up by Alicia Shepherd in her 1994 American Journalism Review article. Shepherd wrote: "Many journalists feel about anonymous sources the way people in troubled relationships feel about partners: can’t live with them, can't live without them."11

The supporters say anonymous sources help journalists obtain information that might otherwise be unavailable. ${ }^{12}$ Using anonymous sources can help protect the life, liberty, job or property of a source. ${ }^{13}$ A reluctant source can be comforted by the fact that he is going to remain anonymous, which in turn leads to a more complete and open dialogue between journalist and source. ${ }^{14}$ Some suggest that the practice benefits

${ }^{9}$ Tim K. Wulfemeyer and Lori L. McFadden, “Anonymous Attribution in Network News,” Journalism Quarterly (Autumn 1986): 468.

${ }^{10}$ Ibid.

${ }^{11}$ Alicia C. Shepherd, “Anonymous Sources,” American Journalism Review (December 1994): 21.

${ }^{12}$ Ibid.

${ }^{13}$ Ibid.

${ }^{14}$ Ibid. 
diversity of thought in the marketplace of ideas. ${ }^{15}$ Reports obtained from anonymous sources have been significant in changing policies that affect America's silent casualties: victims of rape and incest, police misconduct, and sexual or physical abuse. ${ }^{16}$

In 1994, Washington Post Assistant Managing Editor Bob Woodward said, “The job of a journalist, particularly someone who's spent time dealing in sensitive areas, is to find out what really happened. When you are reporting on inside the White House, the Supreme Court, the CIA or the Pentagon, you tell me how you're going to get stuff on the record. Look at the good reporting out of any of those institutions - it's not on the record."17

Critics, however, suggest that journalism's sagging credibility is partially due to the over reliance on veiled sources. ${ }^{18}$ News consumers find it difficult to evaluate the accuracy of the information presented if anonymous sources are used. ${ }^{19}$ Anonymous sourcing also has been referred to as "quick-fix" journalism - the easiest, fastest and laziest way to glean information. ${ }^{20}$ Some also suggest that the use of anonymous sources can result in slanted news coverage. ${ }^{21}$

\footnotetext{
${ }^{15}$ William B. Blackenburg, “The Utility of Anonymous Attribution,” Newspaper Research Journal (Winter/Spring 1992): 10-23.

${ }^{16}$ Sanford and Noble, “Threats Escalate,” 10-11.

17 Shepherd, “Anonymous Sources,” 19-25.

${ }^{18}$ Douglas Rooks, “A Lack of Communication in the Newspaper Business,” Editor and Publisher 129, no.36 (1996): 48-49.

19 Ibid.

${ }^{20}$ Wulfemeyer and McFadden, “Anonymous Attribution,” 469.

${ }^{21}$ Hugh M. Culbertson, “Veiled Attribution: An Element of Style?” Journalism Quarterly (Autumn 1978): 456-65.
} 
"Identify sources whenever possible," the Society of Professional Journalists Code of Ethics advises. "The public is entitled to as much information as possible on sources' reliability." And, it adds, "Always question sources' motives before promising anonymity. Clarify conditions attached to any promise made in exchange for information. But if in doggedly pursuing a story, you promise not to name a source, keep promises."22

Says Allen H. Neuharth, founder of USA Today and chairman of the Freedom Forum, "There's not a place for anonymous sources. I think there are a few major historical developments that happened in journalism - the Pentagon Papers, maybe Watergate - where anonymous sources had a more positive influence than a negative impact. But on balance, the negative impact is so great that we can't overcome the lack of trust until or unless we ban them.,23

According to Richard M. Smith, chairman and editor in chief of Newsweek magazine, historically unnamed sources have helped to break or advance stories of great national importance, but overuse can lead to distrust among readers and carelessness among journalists. ${ }^{24}$

Fred Brown, co-chair of Society of Professional Journalists Ethics Committee, says that in the less furtive world outside of Washington, anonymity is a disservice to the news audience or reader.

\footnotetext{
${ }^{22}$ Fred Brown, “Anonymous sources needed, but must be used with caution,” Quill 93, no.5 (June/July 2005): 56

${ }^{23}$ Shepherd, “Anonymous Sources,” 19-25.

${ }^{24}$ Fred Brown, “Anonymous sources needed,” 56.
} 


\section{Research Findings on the Use of Anonymous Sources}

The findings regarding the frequency of anonymous attribution explain just how often anonymous sources were used and are still being used.

In a study on print media, Hugh Culbertson examined 12 newspapers ranging in size and influence from the New York Times and Washington Post to the Zanesville (Ohio) Times-Recorder. The study focused on a six-month period ending in August 1974. Some key findings included: ${ }^{25}$

- $33 \%$ of all articles analyzed contained anonymous attribution and substantially more than that in Times and Post.

- Newspapers provided no information for the readers to assess the credibility of the anonymous sources.

- More information was given about anonymous sources in domestic news than in international news.

In a subsequent study, Culbertson analyzed the veiled-attribution practice in Time and Newsweek magazines. He examined one 1976 issue per month of each magazine randomly. The following findings were recorded: ${ }^{26}$

- Anonymous attribution occurred in $70 \%$ of Newsweek's stories and in $75 \%$ of Time’s.

- Heavy reliance on foreign media and official sources in international stories without clarifying who the sources are, leading to vague phrases.

${ }^{25}$ Hugh M. Culbertson, “Veiled News Sources- Who and What Are They?” American Newspaper Publishers Association News Research Bulletin (May 1975): 3-23.

${ }^{26}$ Culbertson, "Veiled Attribution” 456-65. 
- Words suggesting expertise like analyst, scholar, researcher and investigator were common.

Tim Wulfemeyer and Lori McFadden studied the broadcast media in Fall 1982. The authors studied two weeks (Monday-Friday) of network television newscasts - ABC, CBS and NBC - selected randomly and videotaped. 27 newscasts and coded stories were content analyzed. The followings results were found: ${ }^{27}$

- Anonymous attribution was found in about 55\% of the network television news.

- CBS used more anonymous attribution than did NBC or ABC.

- The frequency of anonymous attribution on network television newscasts was about $20 \%$ more than the frequency in daily newspapers.

Byron St. Dizier compared the use of anonymous sources by Florida newspaper reporters in 1974 and in 1984, and found that nearly all of the journalists (100 percent in 1974 and 97 percent in 1984) reported using anonymous sources, but the frequency of use dropped between 1974 and $1984 .^{28}$

In another study, approximately one-third of the interviews in Washington were "off the record." 29 In a content analysis study of "administration-related” stories on network television newscasts, about $50 \%$ of the attributed sentences had unnamed sources.

Researchers from The University of Iowa journalism school conducted a study in 1982 for the American Society of Newspaper Editors on six large papers scattered around

\footnotetext{
${ }^{27}$ Wulfemeyer and McFadden, “Anonymous Attribution,” 469.

${ }^{28}$ Byron St. Dizier, “Reporters’ Use of Confidential Sources, 1974 and 1984: A Comparative Study,” Newspaper Research Journal (Summer 1985): 46

${ }^{29}$ Stephen Hess, The Washington Reporters (Washington. D.C: The Brookings Institution, 1981), 19-20.
} 
the country. Upon interviewing the reporters, the researchers found that in about onethird of the stories the anonymous quotes could easily have been avoided. In some cases the reporters did not know why their sources needed protection. In others, the reporters conceded that they could have persuaded the sources to go on-the-record. In still others, the information attributed to blind sources was not crucial and indeed was duplicated elsewhere in the stories.

A survey of editors of 106 American daily newspapers with more than 100,000 circulation revealed that $92 \%$ of the respondent newspapers used confidential sources in reporting. ${ }^{30}$ While one-fourth of the newspapers used confidential sources frequently, $61 \%$ used them occasionally. ${ }^{31}$ The survey profile indicated that the typical newsroom policy on the use of confidential sources was: ${ }^{32}$

- $98.5 \%$ of the papers used confidential sources as a last resort

- $\quad 98 \%$ did not require reporters to sign a confidentiality agreement.

- $\quad 90.5 \%$ prohibited personal attacks by newspapers.

- $\quad 81.5 \%$ required confidential sources be described as fully as possible.

- $75 \%$ required verification of confidential source information.

- $\quad 77 \%$ required that editors be told the names of anonymous sources.

- $64.5 \%$ subjected stories using confidential sources to prepublication review by legal counsel. ${ }^{33}$

\footnotetext{
${ }^{30}$ Charles N. Davis and Susan D. Ross, "How newspaper editors feel about confidential sources in wake of Cohen v. Cowles,” Newspaper Research Journal 17, no. 3/4 (Summer/Fall 1996): 88-97.

${ }^{31}$ Ibid.

${ }^{32}$ Ibid.

${ }^{33}$ Ibid.
} 
Steven Esposito observed the use of anonymous sources by network television news journalists while covering the Bill Clinton- Monica Lewinsky investigation. ${ }^{34}$ An exhaustive content analysis was conducted using videotaped reports and transcripts obtained between January 21, 1998 and September 9, 1998. ${ }^{35}$ ABC World News, CBS Evening News, NBC Nightly News, and CNN WorldView were analyzed. The following conclusions were noted: ${ }^{36}$

- Veiled or unnamed attribution was included in about $72 \%$ of the stories.

- In 1,107 stories analyzed, there were 2,179 anonymous sources.

- $\quad$ NBC used more anonymous sources than ABC, CBS and CNN.

- The four networks together averaged approximately one anonymous attribution per minute.

- NBC used more unnamed sources than named sources.

A 2003 study identifies the different roles that journalists assumed in breaking news coverage of the September 11 terrorism attacks. The first five hours of breaking news coverage of the September 11 attacks on CNN, ABC, NBC, and CBS was examined through content analysis. During the first five hours of coverage, journalists in these four networks reported information from anonymous sources 55 times. ${ }^{37}$

${ }^{34}$ Esposito, “Anonymous White House,” 1-18.

${ }^{35}$ Ibid., 5.

${ }^{36}$ Ibid., 15.

${ }^{37}$ Amy Reynolds and Brooke Barnett, "They Just in ... How National TV News Handled The Breaking “Live” Coverage of September 11,” Journalism and Mass Communication Quarterly (Autumn 2003): 689-703. 
The Project for Excellence in Journalism studied the news media and came up with the following findings in its State of the News Media 2004 report: ${ }^{38}$

- $28 \%$ of all newspaper articles contained at least one anonymous source. The Project studied U.S. daily newspapers divided into four circulation categories, selected at random four papers from each group and examined four randomly selected dates for each day of the week, spread out from January 8 to October 6 of 2003. The Project then analyzed in detail every article from three section fronts: the front page, metro page and lifestyle page.

- $29 \%$ of nightly television news stories contain anonymous sources. The study encompassed 110 hours of news programming in all three network evening and morning newscasts, an examination of nearly 2,000 separate stories.

In a 2004 survey conducted by the First Amendment Center in collaboration with American Journalism Review to gauge public sentiment about a number of journalism issues, $70 \%$ support the right of journalists to keep sources confidential. ${ }^{39}$ However, that is 15 points below the $85 \%$ who said so in 1997 .

Recent studies, however, indicate that the use of anonymous sources has declined. In 2005, the Project for Excellence in Journalism, headed by Tom Rosenstiel, studied 16 newspapers of varying sizes. In that sample, seven percent of all stories contained at least one anonymous source. ${ }^{40}$ This percentage was down from 29 percent found in a similar sample a year ago.

\footnotetext{
${ }^{38}$ http://www.stateofthenewsmedia.org/2004

${ }^{39}$ Paul McMasters, “Low Marks,” American Journalism Review (August 2004): 72

40 “A Downward Trend in Use of Anonymous Sources,” Nieman Reports 59, no.2 (Summer
} 2005): 38-39 


\section{Opinions of Readers}

Research studies show how the opinions of readers have changed over the years. In 1976, a study by Hugh Culbertson and Nancy Somerick indicated that news consumers' perceptions of story believability vary and are affected by factors other than attribution. ${ }^{41}$ Readers understand that the "cloaking" of sources is justified in some cases. $^{42}$

In a later study done in 1981, Fred Fedler and Tim Counts found that the use of attribution in a story about a controversial issue affected readers' perception of its accuracy and significance and the extent to which they expressed agreement with it.”43 Surprisingly, stories without sources or with unidentified sources were rated more accurate and more significant, and subjects agreed with them more, than stories with a named source.

In 1984, F. Dennis Hale concluded that the type of attribution - no attribution, general attribution (a person's title used without a name) and specific attribution (a named source) - "did not make a substantial difference in reader perceptions." 44

Recent studies, however, indicate that readers increasingly question the use of anonymous sources.

\footnotetext{
${ }^{41}$ Hugh M. Culbertson and Nancy Somerick, "Cloaked Attribution: What Does It Mean to News Readers?” American Newspaper Publishers Association News Research Bulletin (May 1976): 22.

42 Ibid.

${ }^{43}$ Fred Fedler and Tim Counts, "Variations in Attribution Affect Readers' Evaluation of Stories," Newspaper Research Journal 3 (April 1981): 29.

${ }^{44}$ Dennis F. Hale, "Unnamed Sources: Their Impact on the Perception of Stories,” Newspaper Research Journal (Winter 1984): 54.
} 
A 2005 survey conducted by the Pew Research Center for the People and the Press among 1,464 Americans, 52\% of the people believe it is "too risky" for news organizations to use unnamed sources, the reason being that it can result in faulty or unreliable information. On the other hand, $44 \%$ say it is okay because it can yield important news that they otherwise wouldn't get. ${ }^{45}$ But most Americans think the use of confidential sources is at least sometimes justified. Over three-quarters (76\%) think reporters should sometimes be allowed to keep their sources confidential if that is the only way to get information, while $19 \%$ say reporters should always reveal their sources. $^{46}$

In a May 2005 survey, the University of Pennsylvania's Annenberg Public Policy Center polled 1,500 people, with $89 \%$ agreeing that news stories relying on anonymous sources should be questioned for accuracy, with 53\% saying such stories should not be published at all. ${ }^{47}$

\section{Policies involving use of Anonymous Sources}

Like readers’ perceptions, anonymous source policies of newspaper and broadcast organizations have also changed over the years.A 1990 analysis of 40 statements from newspapers and wire services yielded four general conditions for granting anonymity. ${ }^{48}$

- An editor must also know the source.

- $\quad$ The story must be important.

${ }^{45}$ http://people-press.org/reports/display.php3?ReportID=248

${ }^{46}$ Ibid.

${ }^{47}$ University of Connecticut, "National Polls of Journalists and the American Public on First Amendment and the Media Released," May 16, 2005.

${ }^{48}$ Boeyink, “Anonymous Sources Abuses,” 233-246. 
- Anonymity should be a last resort.

- Reasons for anonymity should be explained in the story.

In the broadcast media, Wulfemeyer and McFadden analyzed the three commercial networks (CBS, ABC, and NBC) in 1986 and listed their guidelines on confidential sources. ${ }^{49}$

- Confidential sources should be used as a last resort after every other possibility has been exhausted.(ABC,CBS,NBC)

- Confidential source's information must be verified.(NBC)

- Confidential sources must be highly credible and reliable. (CBS,NBC)

- Information obtained from confidential sources must be newsworthy. (CBS)

- Confidential source's quotes must be balanced with opposing viewpoints. (ABC)

- Confidential sources must be described completely without risking sourcereporter relationship. (ABC, CBS, NBC).

- Information regarding the source's motivation should be provided if the source is suspected to have a vested interest in the issue.

- The names of confidential sources should be divulged to news executives if required.

In recent years, newspaper organizations have come up with more stringent rules and policies for using anonymous sources.

In 1999, the Washington Post listed its guidelines on attributing sources. ${ }^{50}$ Before any information is accepted without full attribution, reporters must make every

\footnotetext{
${ }^{49}$ Wulfemeyer and McFadden, “Anonymous Attribution,” 469-470.

${ }^{50}$ http://www.asne.org/ideas/codes/washingtonpost.htm.
} 
reasonable effort to get it on the record. If that is not possible, reporters should consider seeking the information elsewhere. If that in turn is not possible, reporters should request an on-the-record reason for concealing the source's identity and should include the reason in the story.

In March 2004, The New York Times updated their confidential source policy. According to this policy, using anonymous sources required adhering to the following principles. ${ }^{51}$

- The use of unidentified sources is reserved for situations in which the newspaper could not otherwise print information it considers reliable and newsworthy.

- In routine interviewing, anonymity should not be offered to a source.

- Whenever anonymity is granted in sensitive stories, the reader must be told as much as possible about the placement and motivation of the source.

- Anonymous sources should not be used when sources that can be named are readily available.

- Anonymity is not granted to people who are engaged in speculation, unless the very act of speculating is newsworthy and can be labeled for what it is.

- Anonymity is not granted to people who use it as cover for a personal or partisan attack.

- Anonymity should not be invoked for a trivial comment.

The Los Angeles Times also updated its ethics guidelines in October of 2005.

${ }^{52}$ According to those guidelines,

\footnotetext{
${ }^{51}$ http://www.asne.org/index.cfm?ID=387

${ }^{52}$ http://www.asne.org/ideas/codes/losangelestimes.htm.
} 
- Anonymous sources should only be used when conveying important information to the readers.

- Sources should never be permitted to use anonymity as a shield to voice speculation or to make personal attacks.

- An unnamed source should have a compelling reason for insisting on anonymity, such as fear of retaliation, and stories should state those reasons when they are relevant.

- Stories should identify sources as completely as possible consistent with the promise of anonymity.

- When practical, a reporter should consult an editor before entering into an agreement to protect a source's anonymity. In some cases, an editor may insist on knowing the source's identity in order to evaluate the reliability of the information provided.

In December of 2005, the Associated Press managers came up with a strict set of guidelines. ${ }^{53}$ Under AP's rules, material from anonymous sources may be used only if:

- The material is information and not opinion or speculation, and is vital to the news report.

- The information is not available except under the conditions of anonymity imposed by the source.

- The source is reliable, and in a position to have accurate information. In addition, reporters intending to use anonymous sources must get approval from their news manager before sending the story to the desk. The news manager then vets the

\footnotetext{
${ }^{53}$ http://www.asne.org/index.cfm?ID=6120
} 
material and makes sure it meets AP guidelines. ${ }^{54}$ The manager must know the identity of the source, and is obligated, like the reporter, to keep the source's identity confidential. Only after they are assured that the source material has been vetted should editors allow it to be transmitted. ${ }^{55}$

The broadcast media have also framed their ethical guidelines according to the changing times. In September 2000, the Radio-Television News Directors Association (RTNDA) established a Code of Ethics and Professional Conduct. On anonymity, the RTNDA listed the following guidelines.

- Identify sources whenever possible.

- Confidential sources should be used only when it is clearly in the public interest to gather or convey important information or when a person providing information might be harmed.

- Journalists should keep all commitments to protect a confidential source.

\section{Public Journalism}

In the last 15 years, a challenge to the traditional way journalists practiced their craft emerged. ${ }^{56}$ In traditional journalism, the values of fairness, balance and detachment are emphasized. ${ }^{57}$ Public journalism questions the ideal of journalist as detached

${ }^{54}$ Ibid.

${ }^{55}$ Ibid.

${ }^{56}$ David M. Arant and Philip Meyer, "Public Journalism and Traditional Journalism: A Shift in Values?” Journal of Mass Media Ethics 13, no.4 (1998): 205.

${ }^{57}$ Philip Meyer, “Moral Confusion: The what, why and how of journalism is changing,” Quill (November/December 1994): 31-33. 
observer. $^{58}$ It called on journalists and other employers in newspaper organizations to become more involved in community affairs and to take leadership roles in community organizations and even stimulating community examination of local needs by sponsoring forums of public discourse. ${ }^{59}$

Young Choi, an associate professor in the Department of Communication and Information at Hankuk University of Foreign Studies in Seoul, Korea, described four tenets of public journalism: ${ }^{60}$

1. Public journalism should have a democratizing effect.

2. Public journalism should encourage common ground.

3. Public journalism should suggest solutions.

4. Public journalism should develop systematic communication.

Public journalism rose as a movement in the late eighties. In 1967, some $73 \%$ of adults read the paper everyday; in 1988 , it dwindled to $51 \% .{ }^{61}$ In $1988,55 \%$ of Americans said they were dissatisfied with the way things were going in the nation. ${ }^{62}$ The ties that bind people to their communities were loosening, meaning a looser connection to journalism. ${ }^{63}$ The gap between citizens and government was widening. This perception also emerged due to the press' dismal performance in the 1988 presidential campaign

\footnotetext{
${ }^{58}$ Louis W. Hodges, "Ruminations about the Communitarian Debate," Journal of Mass Media Ethics 11, no.3 (1996): 133.

59 Ibid.

${ }^{60}$ Young Choi, “Study Examines Daily Public Journalism at Six Newspapers,” Newspaper Research Journal 25, no. 2 (Spring 2004): 12-27.

${ }^{61}$ Ibid., 22.

62 Davis "Buzz” Merritt, Public Journalism and public Life: Why telling the news is not enough, (Hillsdale, N.J: Erlbaum, 1995).

${ }^{63}$ Rosen, What are Journalists for?, 54.
} 
coverage. ${ }^{64}$ The coverage portrayed politics as an intricate and exclusive game, a public spectacle which attracted large number of spectators. The press serving as host seldom questioned assigned roles: politicians played, citizens watched. ${ }^{65}$ According to Rosen, this left a question: If the press shapes the politics we have, then how can it shape the politics we need? ${ }^{66}$ Public journalism became a reply to that question.

\section{Opinions for and against public journalism}

According to Arant and Meyer, public journalism pulls back from detachment. ${ }^{67}$ The press can seek to sustain an open and free dialogue with and within the community. ${ }^{68}$ It helps people in the community, helps community solve problems, improves community morale and works with civic groups in community improvement projects. ${ }^{69}$ Public journalism seeks to bridge the widening gap between the individual and government. ${ }^{70}$

According to Lee, public journalism can also create a strong alliance between educators and reporters. $^{71}$

On the other hand, Barney contends that public journalism can result in the loss of individuality and autonomy. ${ }^{72}$ According to him, media desperation creates unconditional

\footnotetext{
${ }^{64}$ Theodore L. Glasser and Stephanie Craft, "Public Journalism and the Prospects for Press Accountability,” Journal of Mass Media Ethics 11, no.3 (1996): 154.

65 Ibid.

${ }^{66}$ Rosen, What are Journalists for?, 55.

${ }^{67}$ Arant and Meyer, “Public Journalism?” 206.

${ }^{68}$ Glasser and Craft, “Public Journalism and the Prospects for Press Accountability,” 154.

${ }^{69}$ Ibid., 213.

${ }^{70}$ Lucy Lee, Building Successful Relationships With The Media (Wiley company, 2000), 59.

${ }^{71}$ Ibid.

72 Ralph D. Barney, “Community Journalism: Good Intentions, Questionable Practice,” Journal of Mass Media Ethics 11, no.3 (1996): 140.
} 
membership in professional communities which can blind media to their function of stimulating participation in the decision-making processes resulting in the media pandering to the society. ${ }^{73}$ Barney also says that the group importance can surpass the value of distributing accurate information. ${ }^{74}$ Also the decisions by these groups can be flawed by ignorance due to information restrictions and narrowness of shared values. ${ }^{75}$

\section{Case Studies involving Public Journalism}

In one study in 1987, the editors at the Columbus (GA) Ledger-Enquirer planned a series of articles to examine the issues the city needed to address in the future. ${ }^{76}$ Through in-depth interviews with local residents, experts and influential figures in town, the paper found what the residents wanted the city to become. In the spring of 1988, an eight-part series called “Columbus: Beyond 2000,” was published. The series produced a complete portrayal of the city and its problems. The editors of the paper took an additional step and organized a public meeting where residents could discuss the future of the city. ${ }^{77}$ United Beyond 2000, a new civic organization, came out of that meeting. The organization helped address problems concerning recreation, childcare, race relations, and the special problems of teenagers in Columbus. The Beyond 2000 project enhanced the credibility and reputation of Ledger-Enquirer. ${ }^{78}$

In May 1992, the acquittal of three police officers charged in the video taped

\footnotetext{
${ }^{73}$ Ibid., 143.

${ }^{74}$ Ibid., 145.

${ }^{75}$ Ibid., 148.

${ }^{76}$ Rosen, What are Journalists for?, 28.

${ }^{77}$ Ibid., 29.

${ }^{78}$ Ibid., 31.
} 
beating of a black man set off a series of riots in different parts of the country. ${ }^{79}$ Various newspapers covering the incident moved onto other issues once the dust settled. The editors at the Akron Beacon Journal decided to stay put and launched an experiment in public journalism to address the racial problem. This resulted in a yearlong reporting series titled "A question of color," explaining the disparities and large gaps in perception between blacks and whites. ${ }^{80}$ The ugly realities found during 12 months of reporting prompted the paper to write a second installment of articles in May 1993 titled "Getting Involved: What Can We Do?”81 The Beacon Journal invited civic groups, religious organizations, and schools to propose projects to develop race relations and served as the connecting medium between like-minded people in touch with one another. In response to the newspaper's invitation, more than one hundred organizations comprising civic, church and leadership groups attended and formed an organization named Coming Together. ${ }^{82}$ Coming Together was incorporated as a non-profit group under federal tax law in August 1995. ${ }^{83}$ Beacon Journal was awarded the 1994 Pulitzer Prize for Public Service. $^{84}$

\footnotetext{
${ }^{79}$ Ibid., 92.

${ }^{80}$ Ibid., 95.

${ }^{81}$ Ibid.

${ }^{82}$ Ibid., 96.

${ }^{83}$ Ibid.

${ }^{84}$ Ibid., 97.
} 


\section{$\underline{\text { Research Findings on Public Journalism }}$}

Most of the public or civic journalism studies conducted from 1995 to 2001 focused on three distinct categories of empirical literature: content, journalists and audience. $^{85}$

A new study by University of Wisconsin-Madison revealed some key findings. The study called, “Measuring Civic Journalism’s Progress,” analyzed 651 projects published between 1994 and 2002 and collected by the Pew Center for Public Journalism. According to the study, at least one fifth of all U.S. daily newspapers -- 322 of the nation's 1,500 dailies -- practiced some form of civic journalism between 1994 and 2001, and nearly all credit it with a positive impact on the community.

Scott Maier and Deborah Potter examined how public journalism shaped television news coverage of the 1996 election campaign. ${ }^{86}$ They found that broadcasters who committed to practice public journalism devoted more airtime to policy issues and less to election polls than other stations. But the differences were not statistically significant. However, coverage in newspapers committed to public journalism was substantively different from other papers.

In a 2004 study, Young Choi examined differences in practicing public journalism principles between public journalism and non-public journalism online newspapers and between public journalism newspapers and their counterpart print versions. That data

${ }^{85}$ Brian Massey and Tanni Haas, "Does Making Journalism More Public Make a Difference? A Critical Review of Evaluative Research on Public Journalism,” Journalism and Mass Communication Quarterly 79, no.3 (2002):559-586.

${ }^{86}$ Scott R. Maier and Deborah Potter, "Public Journalism Through the Lens: How Television Broadcasters Covered Campaign '96,” Journal of Broadcasting and Electronic Media 45, no.2, (Spring 2001): $320-334$ 
included 1,364 online stories and 820 print stories from six different newspapers. ${ }^{87}$ Choi found that the study revealed few differences between public and non-public online papers in their practice of public journalism principles. Also, online and print editions of the public journalism newspapers did not show that public journalism is better practiced online.

Renita Coleman and Ben Wasike studied the use of visual elements such as photographs and graphic elements in public journalism and traditional newspapers during the general election of $2000 .^{88}$ They found that public journalism newspapers used more graphic elements to convey issues and analysis and to present information that helps citizens contact journalists than did traditional journalism.

A 2001 survey by the Associated Press Managing Editors (APME) and the National Conference of Editorial Writers (NCEW) along with the Pew Center for Public Journalism revealed that 66 percent of respondents, mainly editors, said they either embraced the label or liked the philosophy and tools of public journalism. ${ }^{89}$

A 2002 study of U.S. journalists by David Weaver and his colleagues showed that three broad societal goals associated with public journalism received solid approval. ${ }^{90}$ $72 \%$ of the journalists approved ordinary people given a chance to express their views on

${ }^{87}$ Young Choi, “Public Journalism at Six Newspapers,” 12-27.

${ }^{88}$ Renita Coleman and Ben Wasike, "Visual Elements in Public Journalism Newspapers in an Election: A Content Analyses of the Photographs and Graphics in Campaign 2000,” Journal of

Communication, September 2004: 456-473.

${ }^{89}$ Campaign Study Group, “Journalism Interactive: New Attitudes, Tools and Techniques Change Journalism's Landscape” (Springfield, Va.: Pew Center for Civic Journalism, 2001). A study conducted for Associated Press Managing Editors, Pew Center for Civic Journalism, National Conference of Editorial Writers by Campaign Study Group.

${ }^{90}$ David Weaver, Randal Beam, Bonnie Brownlee, Paul Voakes, and Cleveland Wilhoit, "The American Journalist in the $21^{\text {st }}$ Century: Key Findings." Paper presented at the annual convention of the Association for Education in Journalism and Mass Communication, Kansas City, MO. 
public affairs, 65\% approved motivating ordinary people to get involved in public discussions of important issues, and 58\% approved pointing people toward possible solutions to society's problems.

Few studies have been conducted on the sourcing aspect of public journalism. Seow Ting Lee, a doctoral student from University of Missouri-Columbia, evaluated the use of non-elite and elite actors and sources in two daily newspapers: the public journalism newspaper St. Louis Post-Dispatch and the traditional, non-public journalism The Washington Post. ${ }^{91}$ He found that the public journalism paper used more non-elite sources and actors compared to the non-public journalism paper.

In a similar study, Jennifer Rousch, a master's student from West Virginia University, performed a thesis study to analyze the use of "elite," media savvy, and "nonelite," non-media savvy, sources in civic and traditional journalism. ${ }^{92}$ Rousch looked at four newspaper series about mining and aging - with two papers from traditional journalism (Charleston Gazette and The Ventura County Star) and two from public journalism (The Herald Dispatch and Savannah Morning News). Rousch found that public journalism newspapers used more non-elite sources compared to traditional journalism newspapers.

One of the limitations of most of the previous research is the lack of literature available on the use of anonymous sources by news organizations that follow public journalism. Most of the literature available on anonymous sources is focused on news

91 Seow Ting Lee, "Public Journalism and Non-Elite Actors and Sources," Newspaper Research Journal 22, no.3 (Summer 2001): 92-95

92 Jennifer Rousch, Elite and Non-elite sourcing in Civic and Traditional Journalism News Projects (Master’s Thesis, West Virginia University, 2003). 
organizations which follow traditional journalism, as opposed to public journalism. Given that public journalism has gained in popularity in recent years and some form of public journalism was practiced in almost one-fifth of all U.S. daily newspapers, according to a 2002 study by the University of Wisconsin-Madison, this is a significant shortcoming. ${ }^{93}$

\section{Hypotheses}

In order to address the aforementioned shortcoming, this thesis study examined the differences in using anonymous sources between public and traditional journalism newspapers. A set of hypotheses was proposed to answer this question.

H1: The frequency of anonymous sources used is greater in traditional journalism articles than public journalism articles.

H2: Traditional journalism news articles contain greater paraphrased anonymous attributions than public journalism articles

H3: Traditional journalism news articles use greater anonymous direct or partial quotes than public journalism.

\section{Methodology}

In the study, a content analysis of the 2004 presidential election campaign coverage was conducted on four newspapers - two traditional journalism papers and two public journalism papers. Of the four newspapers, two were West Virginia papers - The Charleston Gazette and The Herald Dispatch and two were Ohio papers, Dayton Daily News and Akron Beacon Journal. The Charleston Gazette and Dayton Daily News are traditional journalism papers while The Herald Dispatch and Akron Beacon Journal are papers which practice public journalism.

\footnotetext{
${ }^{93}$ http://www.pewcenter.org/doingcj/spotlight/index.php
} 
Papers were designated as public journalism papers if they practiced the following criteria: Focusing attention on issues, using ordinary citizens as news sources, having policy makers listen to the voices of citizens in town hall meetings and public forums, and suggesting solutions for the problems at hand.

The Akron Beacon Journal launched one of the most widely acclaimed public journalism campaigns called “A Question of Color” in 1993 to address racial problems in the country. This campaign was subsequently awarded the 1994 Pulitzer Prize for publicservice journalism. Similarly, The Herald Dispatch has embarked on a number of visible public journalism projects. Also, the Herald Dispatch was chosen as a public journalism paper in a 2003 thesis study by Jennifer Rousch. ${ }^{94}$

Additionally, Akron Beacon Journal and Dayton Daily News have similar readership in the range of $125,000-135,000$. Therefore, those two papers were chosen from Ohio.

Both West Virginia and Ohio were swing states during the election campaign and were therefore chosen. Every article written by a staff writer on George Bush, John Kerry, Dick Cheney and John Edwards from June 1, 2004 to November 2, 2004 was analyzed for anonymous source usage. Associated Press articles and articles from local news-wire services were ignored. Editorials, columns and letters to the editor were excluded. There was one common condition used for selecting articles - the article should in some way be related to the presidential election. Articles covering people stumping for George Bush or John Kerry were also included. For example, if Laura Bush

\footnotetext{
${ }^{94}$ Jennifer Rousch, Elite and Non-elite sourcing in Civic and Traditional Journalism News Projects (Master's Thesis, West Virginia University, 2003).
} 
came to West Virginia or Vanessa Kerry went to Ohio to stump for their candidates, those articles were included.

The following operational definitions were used for coding these articles.

Traditional Journalism: Any newspaper or news stories that does not promote community advocacy. ${ }^{95}$

Public Journalism: Furthers community advocacy. Reporters and newspapers act as advocates for the community by interacting in the community with public meetings, organizing community groups and instigating social change through writing and reporting. Public or civic journalists hold public forums and meeting with the community to create dialogue and provide forums for debate. ${ }^{96}$

Source: A named or anonymous individual or individuals who provide opinion or information in a direct quote, partial quote or paraphrase. ${ }^{97}$

Anonymous Source: A source whose name and job position are not mentioned while providing a direct quote, partial quote or paraphrase.

Anonymous Source with an identifier: A source whose job position or title is mentioned, but name is omitted, while providing a direct quote, partial quote or paraphrase.

Known Source: A direct or paraphrased comment attributed to an individual or individuals with name mentioned. ${ }^{98}$

\footnotetext{
95 Jennifer Rousch, Elite and Non-elite sourcing in Civic and Traditional Journalism News Projects (Master's Thesis, West Virginia University, 2003).

${ }^{96}$ Ibid.

${ }^{97}$ Randall S. Sumpter and Melissa A. Braddock, "Source use in a "News Disaster” Account: A Content Analysis of Voter News Service Stories,” Journalism and Mass Communication Quarterly 79, no.3 (Autumn 2002): 543.
} 
The various categories with its sub-categories are explained (in the figure).

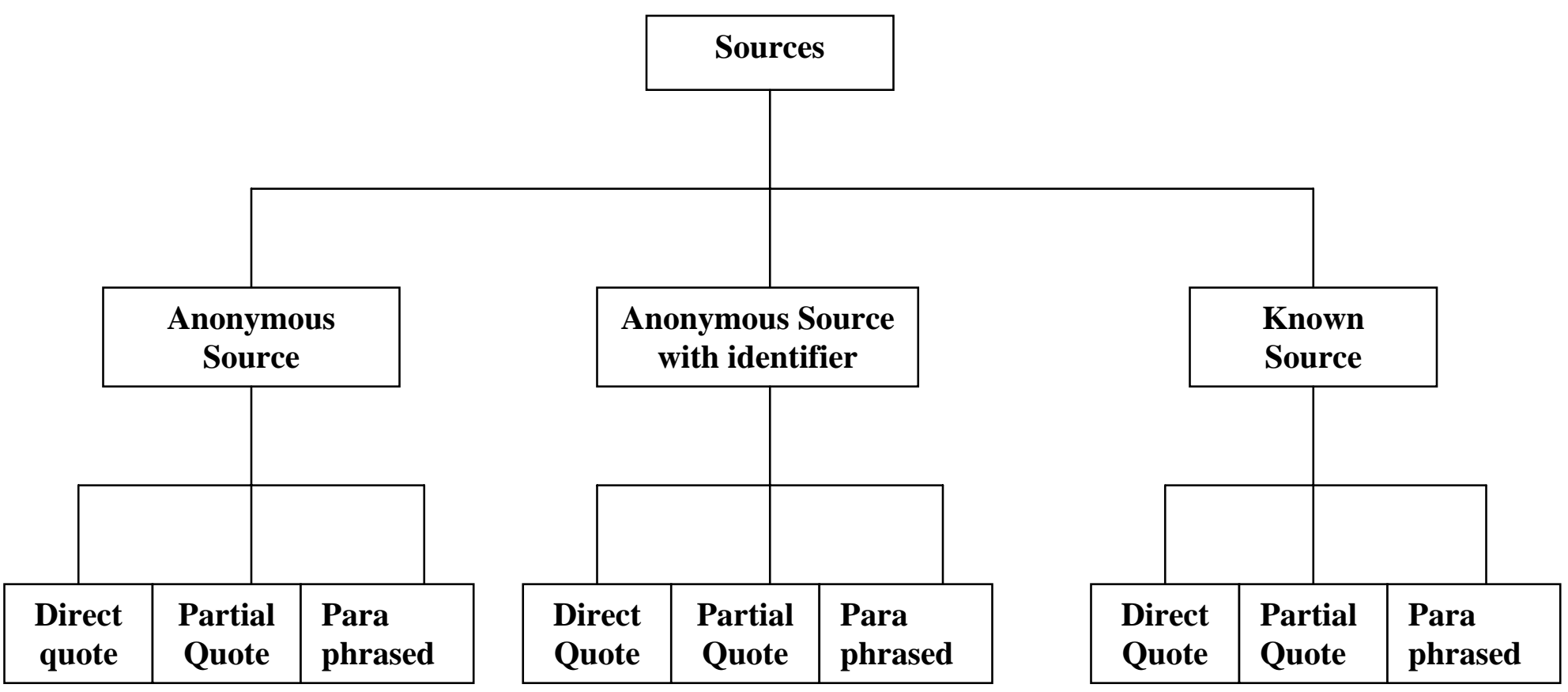

During analysis, the names of independent organizations were considered as known sources. For example, the White House Office said or The Bush Campaign said was construed to be known sources. This was done because organizations sometimes issued statements to the press in which case it was considered as a known source. But a statement like a White House Official said was construed as an anonymous source with an identifier.

While analyzing anonymous sources, some exceptions were observed. If during a question and answer session with one of the candidates, a member from the audience was quoted as asking a question without furnishing his/her name, then that source was not considered as an anonymous source. This was done because of the difficulty in getting the name of the source in such a large crowd. Similarly, if the reporter was doing some observational reporting while following the candidates in their campaign trail, and used

${ }^{98}$ Ibid. 
quotes and paraphrased attributions from people without naming them, then that source was not considered as an anonymous source.

For example, if John Kerry were to enter a restaurant and have a conversation with the waitress and people in that restaurant, then the names of the waitress and people in that restaurant don't have to be given even though the conversation is published in the newspaper. This would be treated as an instance of observational reporting.

\section{$\underline{\text { Results }}$}

The data included a total of 295 articles with 159 articles from Traditional Journalism newspapers and 136 articles from Public Journalism newspapers. In this data set, 81 articles were from the Charleston Gazette, 78 from Dayton Daily News, 87 from Akron Beacon Journal and 49 from The Herald Dispatch. The Herald Dispatch had fewer articles because it is a small-sized paper limited to readership from Huntington residents. A summary of the data is given in Table 1.

Table 1:Summary of Anonymous Source Usage

\begin{tabular}{|c|c|c|c|c|c|c|}
\hline Type of & Number of & Known & Anonymous & Known & Anonymous & Anonymous \\
\hline \multirow[t]{2}{*}{ Journalism } & Articles & Sources & Sources & Attributions & Attributions & Quotes \\
\hline & $\#$ & \# & $\#$ & $\#$ & $\#$ & $\#$ \\
\hline & & & & & & \\
\hline Traditional & 159 & 840 & 47 & 1232 & 48 & 3 \\
\hline \multicolumn{7}{|l|}{ Journalism } \\
\hline & & & & & & \\
\hline & & & & & & \\
\hline Public & 136 & 650 & 18 & 940 & 18 & 2 \\
\hline \multicolumn{7}{|l|}{ Journalism } \\
\hline & & & & & & \\
\hline
\end{tabular}


A further breakdown of this data with respect to each newspaper is given in Table 2.

Table 2: Breakdown of Anonymous Source Usage Data for Each Newspaper

\begin{tabular}{|c|c|c|c|c|c|c|c|}
\hline Paper & Articles & Anonymous & Anonymous & Anonymous & Anonymous & Total & Total \\
\hline & & Sources & sources & Attributions & Quotes & Sources & Attributions \\
\hline & & & (identifier) & & & & \\
\hline & $\#$ & $\#$ & $\#$ & $\#$ & $\#$ & $\#$ & $\#$ \\
\hline Charleston & 81 & 4 & 24 & 30 & 1 & 436 & 625 \\
\hline \multicolumn{8}{|l|}{ Gazette } \\
\hline & & & & & & & \\
\hline & & & & & & & \\
\hline Dayton & 78 & 2 & 17 & 18 & 2 & 451 & 655 \\
\hline \multicolumn{8}{|l|}{ Daily } \\
\hline \multicolumn{8}{|l|}{ News } \\
\hline & & & & & & & \\
\hline & & & & & & & \\
\hline & & & & & & & \\
\hline Herald & 49 & 2 & 5 & 7 & 0 & 230 & 355 \\
\hline \multicolumn{8}{|l|}{ Dispatch } \\
\hline & & & & & & & \\
\hline & & & & & & & \\
\hline Akron & 87 & 3 & 8 & 11 & 2 & 438 & 603 \\
\hline \multicolumn{8}{|l|}{ Beacon } \\
\hline \multicolumn{8}{|l|}{ Journal } \\
\hline & & & & & & & \\
\hline & & & & & & & \\
\hline
\end{tabular}

A complete analysis of the number of sources, attributions and quotes for every article is listed in the Appendix section

\section{Frequency of Anonymous Sources (Hypothesis 1)}

A cursory look at the table indicates that traditional journalism newspapers use more anonymous sources than public journalism newspapers. In order to check if these differences are statistically significant, a chi-square test was conducted. The results of the chi-square test are shown in Table 3 . From the chi-square test, it is evident that for $\mathrm{p} \leq$ 0.025 the total chi-square value of 6.45 exceeds the critical chi-square value of 5.024 . Therefore, this hypothesis is accepted. 
Table 3:Chi-Square Test to Check Hypothesis 1

\begin{tabular}{|c|c|c|c|}
\hline Type of & Anonymous & Known & Total \\
\hline Journalism & Sources & Sources & $\#$ \\
\hline $\begin{array}{c}\text { Traditional } \\
\text { Observed }\end{array}$ & $\#$ & 840 & 887 \\
\hline & 47 & & \\
\hline $\begin{array}{c}\text { Traditional } \\
\text { Expected }\end{array}$ & 37.07717042 & 849.9228296 & 668 \\
\hline & 18 & 650 & \\
\hline Public Observed & & & \\
\hline Public Expected & 27.92282958 & 640.0771704 & \\
\hline & 65 & & 1555 \\
\hline Total & & & \\
\hline
\end{tabular}

\begin{tabular}{|c|c|}
\hline Chi-Square Values & \\
\hline Traditional/Anonymous & 2.655611143 \\
\hline Public/Anonymous & 3.526238149 \\
\hline Traditional/Known & 0.115848808 \\
\hline Public/Known & 0.153829181 \\
\hline Total Ch-Square & 6.451527282 \\
\hline DOF & 1 \\
\hline$P \leq 0.025$ & $\begin{array}{l}\text { Critical Chi-square value }= \\
5.024\end{array}$ \\
\hline $\begin{array}{l}\text { There is a statistically significant } \\
\text { difference }\end{array}$ & \\
\hline
\end{tabular}

\section{Frequency of paraphrased anonymous attributions (Hypothesis 2)}

From Table 1, it is clear that traditional journalism newspapers use more paraphrased anonymous attributions than newspapers which practice public journalism. Again, a chisquare test similar to the one used for hypothesis 1 was conducted to test for statistical significance as shown in Table 4 . A chi-square value of 6.7 was obtained which exceeds 
the critical chi-square value of 5.024 ( $\mathrm{p} \leq 0.025)$. Therefore, this hypothesis is also accepted.

Table 4: Chi-Square Test to Check Hypothesis 2

\begin{tabular}{|c|c|c|c|}
\hline Type of & Total Number of & Total Number & Total number \\
\hline Journalism & Anonymous & of Known & of Attributions \\
\hline & Attributions & Attributions & \\
\hline $\begin{array}{c}\text { Traditional } \\
\text { Observed }\end{array}$ & 48 & 1232 & 1280 \\
\hline $\begin{array}{c}\text { Traditional } \\
\text { Expected }\end{array}$ & 37.74798928 & 1242.252011 & \\
\hline & 18 & 940 & 958 \\
\hline Public Observed & & & \\
\hline Public Expected & 28.25201072 & 929.7479893 & \\
\hline & 66 & 2172 & 2238 \\
\hline
\end{tabular}

\begin{tabular}{|l|c|}
\hline Chi-Square Values & \multicolumn{1}{|c|}{2.784352913} \\
\hline Traditional/Anonymous & 3.72022101 \\
\hline Public/Anonymous & 0.084607409 \\
\hline Traditional/Known & 0.11304539 \\
\hline Public/Known & $\mathbf{6 . 7 0 2 2 2 6 7 2 2}$ \\
\hline & $\mathbf{1}$ \\
\hline Total Ch-Square & \\
\hline DOF & \multicolumn{1}{|c|}{} \\
\hline & $\begin{array}{l}\text { Critical Chi-square value }= \\
\mathbf{5 . 0 2 4}\end{array}$ \\
\hline P $\mathbf{0 . 0 2 5}$ & \\
\hline $\begin{array}{l}\text { There is a statistically significant } \\
\text { difference }\end{array}$ & \\
\hline
\end{tabular}

\section{Frequency of Direct or Partial Anonymous Quotes (Hypothesis 3)}

From Table 1, it is apparent that there is not much of a difference between traditional and public journalism newspapers in the use of direct or partial anonymous quotes. As you can see, the frequency in both forms of journalism is less than 5 . This precludes the need 
for a statistical test and it can be easily inferred that there is no statistical difference. Therefore this hypothesis is rejected.

\section{Discussion, Limitations and Future Studies}

The study examined the usage of anonymous sources in two traditional and two public journalism newspapers during the 2004 presidential election campaign. The analysis revealed that traditional journalism newspapers used significantly more anonymous sources and attributions from those sources compared to public journalism papers.

One of the glaring differences between public and traditional newspapers was the tendency of traditional journalism newspapers to use anonymous sources with identifiers. When no names and titles were used for sources i.e. when the source was totally anonymous, both papers had similar numbers ( 6 by traditional journalism newspapers and 5 by public journalism newspapers). In contrast, when the source was referred by means of only title and no name i.e. anonymous source with identifier, traditional journalism newspapers used more than three times the number of such sources when compared to public journalism newspapers (41 by traditional journalism newspapers and 13 by public journalism newspapers).

This could be because of the tendency of traditional newspapers to use more government or expert sources, who may not like to give out their names, especially if the information is sensitive. On the other hand, public journalism newspapers use more nonelite sources (Based on Seow Ting Lee's and Jennifer Rousch’s studies). As a result, the sources are more likely to give their names without reservations. 
"Officials said" seemed to be the most common form of anonymous source used with traditional newspapers using it 12 times and public journalism using it three times. Anonymous expert sources came second with traditional newspapers using it seven times and public journalism newspapers using it five times. Other types of anonymous sources used frequently were "Spokesman said" and "Organizers said." (For a complete breakdown of the different types of anonymous sources used, please refer Appendix).

Both traditional and public journalism newspapers used very few anonymous sources, indicating that reporters are normally very careful in naming sources while using a "Direct" or "Partial" quote.

One of the limitations of the study is the number of papers analyzed. Only four newspapers were examined from two states. As a result, it is hard to generalize the results of the study. Also, the articles were coded by only one observer. So, there is a possibility of error creeping in during the sampling process. Coding the articles with more than one observer could possibly eliminate some of the errors that might have crept in during the analysis.

Another limitation is the difference in the number of articles between the two types of journalism. There were 159 traditional journalism articles and 136 public journalism articles. This was mainly because of the fact that The Herald Dispatch had only 49 articles, compared to the 80 some articles from other newspapers. Herald Dispatch is a small-sized newspaper mostly limited to readers from Huntington. As a result, the coverage was mostly related to local news.

A more elaborate study that investigates several newspapers from states spread throughout the country would give a better indication of the use of anonymous sources. 
This could be one of the possible future studies. Another possible study is to analyze the same newspapers during the 2000 presidential campaign and compare it with the results obtained in this study. This would not only give an indication of whether public journalism is doing a better job of using fewer anonymous sources compared to traditional journalism but would also show whether the use of anonymous sources has declined over time. 


\section{Bibliography}

Adams, B. John. "The Relative Credibility of 20 unnamed sources.” Journalism Quarterly 39 (Winter 1962): 79-82.

Arant, M. David and Philip Meyer. "Public Journalism and Traditional Journalism: A Shift in Values?” Journal of Mass Media Ethics 13, no.4 (1998): 205-218.

Archibald, J. Samuel. "Rules for the game of the ghost.” Columbia Journalism Review (Winter 1967-1968): 17-23.

Barney, D. Ralph. “Community Journalism: Good Intentions, Questionable Practice.” Journal of Mass Media Ethics 11, no.3 (1996): 140-151.

Blackenburg, B. William. "The Utility of Anonymous Attribution.” Newspaper Research Journal (Winter/Spring 1992): 10-23.

Boeyink, E. David. “Anonymous Sources in News Stories: Justifying Exceptions and Limiting Abuses.” Journal of Mass Media Ethics 5, no.4 (1990): 233-246.

Campaign Study Group, “Journalism Interactive: New Attitudes, Tools and Techniques Change Journalism’s Landscape” (Springfield, Va.: Pew Center for Civic Journalism, 2001). A study conducted for Associated Press Managing Editors, Pew Center for Civic Journalism, National Conference of Editorial Writers by Campaign Study Group.

Coleman, Renita and Ben Wasike. "Visual Elements in Public Journalism Newspapers in an Election: A Content Analyses of the Photographs and Graphics in Campaign 2000.” Journal of Communication, September 2004: 456-473.

Choi, Young . "Study Examines Daily Public Journalism at Six Newspapers.” Newspaper Research Journal 25, no. 2 (Spring 2004): 12-27.

Culbertson, M. Hugh. “Veiled News Sources- Who and What Are They?” American Newspaper Publishers Association News Research Bulletin (May 1975): 3-23.

Culbertson, M. Hugh and Nancy Somerick. “Cloaked Attribution: What Does It Mean to News Readers?” American Newspaper Publishers Association News Research Bulletin (May 1976): 22.

Culbertson, M. Hugh. “Veiled Attribution: An Element of Style?” Journalism Quarterly (Autumn 1978): 456-65.

Davis, N. Charles and Susan D. Ross. "How newspaper editors feel about confidential sources in wake of Cohen v. Cowles.” Newspaper Research Journal 17, no. 3/4 (Summer/Fall 1996): 88-97. 
Dizier, Byron St. "Reporters’ Use of Confidential Sources, 1974 and 1984: A

Comparative Study.” Newspaper Research Journal (Summer 1985): 46

Esposito, A. Steven. “Anonymous White House Sources: How They Helped Shape Television News Coverage of the Bill Clinton- Monica Lewinsky Investigation,” Communications and the Law 21, no. 3 (September 1999): 1-18

Fedler, Fred and Tim Counts. "Variations in Attribution Affect Readers' Evaluation of Stories.” Newspaper Research Journal 3 (April 1981): 25-34.

Foreman, Gene. “Confidential Sources: Testing the Readers' Confidence.” Nieman Reports 53/54 no.4/1 (Winter 99/Spring 2000): 123-126.

Fielder, D. Virginia and David H. Weaver. "Public Opinion on Investigative Reporting.” Newspaper Research Journal 4 (January 1982): 54-62.

Glasser, L. Theodore and Stephanie Craft. "Public Journalism and the Prospects for Press Accountability.” Journal of Mass Media Ethics 11, no.3 (1996): 152-158.

Hale, Dennis F. “Unnamed Sources: Their Impact on the Perception of Stories.” Newspaper Research Journal (Winter 1984): 49-56.

Hess, Stephen. The Washington Reporters .Washington. D.C: The Brookings Institution, 1981.

Hodges, W. Louis. "Ruminations about the Communitarian Debate.” Journal of Mass Media Ethics 11, no.3 (1996): 133-139.

Lee, Lucy. Building Successful Relationships With The Media. Wiley company, 2000.

Lee, Seow Ting. "Public Journalism and Non-Elite Actors and Sources.” Newspaper Research Journal 22, no.3 (Summer 2001): 92-95

Maier, Scott R. and Deborah Potter. "Public Journalism Through the Lens: How Television Broadcasters Covered Campaign '96.” Journal of Broadcasting and Electronic Media 45, no.2, (Spring 2001): 320-334

Massey, Brian and Tanni Haas. "Does Making Journalism More Public Make a Difference? A Critical Review of Evaluative Research on Public Journalism.” Journalism and Mass Communication Quarterly 79, no.3 (2002):559-586.

Merritt, Davis. Public Journalism and public Life: Why telling the news is not enough. Hillsdale, N.J: Erlbaum, 1995.

“A Downward Trend in Use of Anonymous Sources.” Nieman Reports 59, no.2 (Summer 2005): 38-39 
Rooks, Douglas. “A Lack of Communication in the Newspaper Business.” Editor and Publisher 129, no.36 (1996): 48-49.

Rosen, Jay. What are Journalists for? New Haven and London: Yale University Press, 1999.

Rousch, Jennifer. Elite and Non-elite sourcing in Civic and Traditional Journalism News Projects. Master's Thesis: West Virginia University, 2003.

Sanford, W. Bruce and Anne R. Noble. "Threats Escalate to Strip Confidential Sources from Reporter’s Tool Kit.” Quill (April 1992): 10-11.

Shepherd, C. Alicia. “Anonymous Sources.” American Journalism Review (December 1994): 19-25.

Sumpter, S. Randall and Melissa A. Braddock. "Source use in a "News Disaster" Account: A Content Analysis of Voter News Service Stories.” Journalism and Mass Communication Quarterly 79, no.3 (Autumn 2002): 539-558.

University of Connecticut. "National Polls of Journalists and the American Public on First Amendment and the Media Released.” May 16, 2005.

Weaver, David, Randal Beam, Bonnie Brownlee, Paul Voakes, and Cleveland Wilhoit, "The American Journalist in the $21^{\text {st }}$ Century: Key Findings." Paper presented at the annual convention of the Association for Education in Journalism and Mass Communication, Kansas City, MO.

Wulfemeyer, K. Tim and Lori L. McFadden. "Anonymous Attribution in Network News.” Journalism Quarterly (Autumn 1986): 468-473. 


\section{Appendix}

\section{Type- Public Journalism, Paper- Herald Dispatch}

\begin{tabular}{|c|c|c|c|c|c|c|}
\hline Article & Known & Anonymous & Anonymous & Anonymous & Anonymous & Anonymous \\
\hline Number & Sources & Sources & Sources & Attributions & Quotes & Source Used \\
\hline & & & $\begin{array}{c}\text { (With } \\
\text { Identifier) }\end{array}$ & (Paraphrases) & & \\
\hline & & & & & & \\
\hline 1 & 1 & 0 & 0 & 0 & 0 & \\
\hline 2 & 2 & 0 & 0 & 0 & 0 & \\
\hline 3 & 3 & 0 & 0 & 0 & 0 & \\
\hline 4 & 8 & 0 & 0 & 0 & 0 & \\
\hline 5 & 2 & 0 & 0 & 0 & 0 & \\
\hline 6 & 8 & 0 & 0 & 0 & 0 & \\
\hline 7 & 4 & 0 & 0 & 0 & 0 & \\
\hline 8 & 4 & 0 & 0 & 0 & 0 & \\
\hline 9 & 8 & 0 & 0 & 0 & 0 & \\
\hline 10 & 3 & 0 & 0 & 0 & 0 & \\
\hline 11 & 5 & 0 & 0 & 0 & 0 & \\
\hline 12 & 1 & 0 & 0 & 0 & 0 & \\
\hline 13 & 2 & 0 & 0 & 0 & 0 & \\
\hline 14 & 2 & 0 & 0 & 0 & 0 & \\
\hline 15 & 1 & 0 & 0 & 0 & 0 & \\
\hline 16 & 2 & 0 & 0 & 0 & 0 & \\
\hline 17 & 4 & 0 & 0 & 0 & 0 & \\
\hline 18 & 6 & 0 & 0 & 0 & 0 & \\
\hline 19 & 4 & 0 & 0 & 0 & 0 & \\
\hline 20 & 7 & 0 & 0 & 0 & 0 & \\
\hline 21 & 6 & 0 & 0 & 0 & 0 & \\
\hline 22 & 4 & 0 & 0 & 0 & 0 & \\
\hline 23 & 7 & 0 & 0 & 0 & 0 & \\
\hline 24 & 10 & 1 & 0 & 1 & 0 & Officials announced \\
\hline 25 & 1 & 0 & 0 & 0 & 0 & \\
\hline 26 & 4 & 0 & 0 & 0 & 0 & \\
\hline 27 & 2 & 0 & 0 & 0 & 0 & \\
\hline 28 & 2 & 0 & 1 & 1 & 0 & $\begin{array}{l}\text { A campaign staffer } \\
\text { said }\end{array}$ \\
\hline 29 & 1 & 0 & 0 & 0 & 0 & \\
\hline 30 & 6 & 0 & 0 & 0 & 0 & \\
\hline 31 & 3 & 0 & 0 & 0 & 0 & \\
\hline 32 & 10 & 0 & 0 & 0 & 0 & \\
\hline 33 & 1 & 0 & 0 & 0 & 0 & \\
\hline 34 & 4 & 0 & 0 & 0 & 0 & \\
\hline 35 & 8 & 0 & 0 & 0 & 0 & \\
\hline 36 & 6 & 0 & 0 & 0 & 0 & \\
\hline 37 & 6 & 0 & 0 & 0 & 0 & \\
\hline 38 & 2 & 0 & 0 & 0 & 0 & \\
\hline 39 & 6 & 0 & 0 & 0 & 0 & \\
\hline
\end{tabular}




\begin{tabular}{|c|c|c|c|c|c|c|}
\hline 40 & 4 & 0 & 0 & 0 & 0 & \\
\hline 41 & 5 & 0 & 0 & 0 & 0 & \\
\hline 42 & 9 & 0 & 0 & 0 & 0 & \\
\hline 43 & 3 & 0 & 0 & 0 & 0 & \\
\hline 44 & 6 & 0 & 0 & 0 & 0 & \\
\hline 45 & 13 & 0 & 0 & 0 & 0 & \\
\hline 46 & 3 & 0 & 2 & 2 & 0 & Analysts say \\
\hline & & & & & & Environmentalists say \\
\hline 47 & 3 & 0 & 0 & 0 & 0 & \\
\hline 48 & 8 & 0 & 0 & 0 & 0 & \\
\hline 49 & 3 & 1 & 2 & 3 & 0 & Analysts expect, \\
\hline & & & & & & Horizon workers say, \\
\hline & & & & & & Officials say \\
\hline 49 & 223 & 2 & 5 & 7 & 0 & \\
\hline
\end{tabular}


Type- Public Journalism, Paper- Akron Beacon Journal

\begin{tabular}{|c|c|c|c|c|c|c|}
\hline Article & Known & Anonymous & Anonymous & Anonymous & Anonymous & Anonymous \\
\hline & Source & Sources & Sources & Attributions & Quotes & Source Used \\
\hline & & & $\begin{array}{c}\text { (With } \\
\text { Identifier) }\end{array}$ & (Paraphrases) & & \\
\hline 1 & 5 & 0 & 0 & 0 & 0 & \\
\hline 2 & 4 & 0 & 0 & 0 & 0 & \\
\hline 3 & 6 & 0 & 0 & 0 & 0 & \\
\hline 4 & 5 & 0 & 0 & 0 & 0 & \\
\hline 5 & 3 & 0 & 0 & 0 & 0 & \\
\hline 6 & 7 & 0 & 0 & 0 & 0 & \\
\hline 7 & 1 & 0 & 0 & 0 & 0 & \\
\hline 8 & 1 & 0 & 0 & 0 & 0 & \\
\hline 9 & 1 & 0 & 0 & 0 & 0 & \\
\hline 10 & 1 & 0 & 0 & 0 & 0 & \\
\hline 11 & 3 & 0 & 1 & 1 & 0 & analysts speculate \\
\hline 12 & 6 & 0 & 0 & 0 & 0 & \\
\hline 13 & 6 & 0 & 0 & 0 & 0 & \\
\hline 14 & 4 & 0 & 0 & 0 & 0 & \\
\hline 15 & 2 & 0 & 0 & 0 & 0 & \\
\hline 16 & 2 & 0 & 0 & 0 & 0 & \\
\hline 17 & 2 & 0 & 0 & 0 & 0 & \\
\hline 18 & 4 & 0 & 0 & 0 & 0 & \\
\hline 19 & 4 & 0 & 0 & 0 & 0 & \\
\hline 20 & 2 & 0 & 0 & 0 & 0 & \\
\hline 21 & 11 & 0 & 0 & 0 & 0 & \\
\hline 22 & 8 & 0 & 0 & 0 & 0 & \\
\hline 23 & 8 & 0 & 0 & 0 & 0 & \\
\hline 24 & 7 & 0 & 1 & 0 & 1 & According to the \\
\hline & & & & & & campaign pool reporter \\
\hline 25 & 7 & 0 & 0 & 0 & 0 & \\
\hline 26 & 6 & 0 & 0 & 0 & 0 & \\
\hline 27 & 5 & 0 & 0 & 0 & 0 & \\
\hline 28 & 5 & 0 & 0 & 0 & 0 & \\
\hline 29 & 4 & 0 & 0 & 0 & 0 & \\
\hline 30 & 8 & 0 & 0 & 0 & 0 & \\
\hline 31 & 4 & 0 & 0 & 0 & 0 & \\
\hline 32 & 3 & 0 & 0 & 0 & 0 & \\
\hline 33 & 3 & 0 & 0 & 0 & 0 & \\
\hline 34 & 3 & 0 & 0 & 0 & 0 & \\
\hline 35 & 4 & 0 & 0 & 0 & 0 & \\
\hline 36 & 2 & 0 & 0 & 0 & 0 & \\
\hline 37 & 3 & 0 & 0 & 0 & 0 & \\
\hline 38 & 1 & 0 & 1 & 1 & 0 & $\begin{array}{c}\text { Bush representatives } \\
\text { said }\end{array}$ \\
\hline 39 & 2 & 0 & 0 & 0 & 0 & \\
\hline 40 & 4 & 0 & 0 & 0 & 0 & \\
\hline 41 & 6 & 0 & 0 & 0 & 0 & \\
\hline
\end{tabular}




\begin{tabular}{|c|c|c|c|c|c|c|}
\hline 42 & 6 & 0 & 0 & 0 & 0 & \\
\hline 43 & 4 & 0 & 0 & 0 & 0 & \\
\hline 44 & 7 & 0 & 0 & 0 & 0 & \\
\hline 45 & 4 & 0 & 0 & 0 & 0 & \\
\hline 46 & 4 & 0 & 0 & 0 & 0 & \\
\hline 47 & 3 & 0 & 0 & 0 & 0 & \\
\hline 48 & 2 & 0 & 0 & 0 & 0 & \\
\hline 49 & 3 & 0 & 0 & 0 & 0 & \\
\hline 50 & 6 & 0 & 0 & 0 & 0 & \\
\hline 51 & 5 & 0 & 0 & 0 & 0 & \\
\hline 52 & 2 & 0 & 0 & 0 & 0 & \\
\hline 53 & 2 & 0 & 0 & 0 & 0 & \\
\hline 54 & 10 & 0 & 0 & 0 & 0 & \\
\hline 55 & 6 & 0 & 1 & 1 & 0 & Bush aides made clear \\
\hline 56 & 9 & 0 & 0 & 0 & 0 & \\
\hline 57 & 9 & 0 & 0 & 0 & 0 & \\
\hline 58 & 7 & 0 & 0 & 0 & 0 & \\
\hline 59 & 4 & 0 & 0 & 0 & 0 & \\
\hline 60 & 4 & 0 & 0 & 0 & 0 & \\
\hline 61 & 1 & 0 & 1 & 1 & 0 & Said a spokeswoman \\
\hline 62 & 13 & 1 & 0 & 1 & 0 & Others say \\
\hline 63 & 6 & 0 & 1 & 1 & 0 & $\begin{array}{c}\text { Campaign aides } \\
\text { estimated }\end{array}$ \\
\hline 64 & 4 & 0 & 0 & 0 & 0 & \\
\hline 65 & 3 & 0 & 0 & 0 & 0 & \\
\hline 66 & 13 & 0 & 0 & 0 & 0 & \\
\hline 67 & 2 & 0 & 0 & 0 & 0 & \\
\hline 68 & 8 & 0 & 0 & 0 & 0 & \\
\hline 69 & 5 & 0 & 0 & 0 & 0 & \\
\hline 70 & 8 & 1 & 0 & 2 & 0 & One man admitted, \\
\hline & & & & & & the man told authorities \\
\hline 71 & 6 & 1 & 0 & 1 & 0 & Critics say \\
\hline 72 & 8 & 0 & 0 & 0 & 0 & \\
\hline 73 & 11 & 0 & 1 & 1 & 1 & A businessman said \\
\hline 74 & 12 & 0 & 1 & 1 & 0 & Election officials report \\
\hline 75 & 1 & 0 & 0 & 0 & 0 & \\
\hline 76 & 2 & 0 & 0 & 0 & 0 & \\
\hline 77 & 3 & 0 & 0 & 0 & 0 & \\
\hline 78 & 5 & 0 & 0 & 0 & 0 & \\
\hline 79 & 3 & 0 & 0 & 0 & 0 & \\
\hline 80 & 3 & 0 & 0 & 0 & 0 & \\
\hline 81 & 12 & 0 & 0 & 0 & 0 & \\
\hline 82 & 6 & 0 & 0 & 0 & 0 & \\
\hline 83 & 6 & 0 & 0 & 0 & 0 & \\
\hline 84 & 6 & 0 & 0 & 0 & 0 & \\
\hline 85 & 2 & 0 & 0 & 0 & 0 & \\
\hline 86 & 5 & 0 & 0 & 0 & 0 & \\
\hline 87 & 4 & 0 & 0 & 0 & 0 & \\
\hline Total & 428 & 3 & 8 & 11 & 2 & \\
\hline
\end{tabular}




\section{Type- Traditional Journalism, Paper- Charleston Gazette}

\begin{tabular}{|c|c|c|c|c|c|c|}
\hline Article & Known & Anonymous & Anonymous & Anonymous & Anonymous & Anonymous Source Used \\
\hline Number & Sources & Sources & Sources & Attributions & Quotes & \\
\hline & & & $\begin{array}{c}\text { with } \\
\text { identifier }\end{array}$ & (Paraphrases) & & \\
\hline 1 & 3 & 0 & 0 & 0 & 0 & \\
\hline 2 & 1 & 1 & 0 & 1 & 0 & Critics say \\
\hline 3 & 3 & 0 & 0 & 0 & 0 & \\
\hline 4 & 4 & 0 & 0 & 0 & 0 & \\
\hline \multirow[t]{2}{*}{5} & 7 & 0 & 1 & 2 & 0 & City officials estimated, \\
\hline & & & & & & City officials described \\
\hline 6 & 2 & 0 & 0 & 0 & 0 & \\
\hline 7 & 2 & 0 & 0 & 0 & 0 & \\
\hline 8 & 5 & 0 & 0 & 0 & 0 & \\
\hline 9 & 6 & 0 & 0 & 0 & 0 & \\
\hline 10 & 9 & 0 & 1 & 1 & 0 & Spokeswoman said \\
\hline 11 & 6 & 0 & 1 & 1 & 0 & One organizer guessed \\
\hline 12 & 2 & 1 & 0 & 1 & 0 & Sources said \\
\hline 13 & 4 & 0 & 0 & 0 & 0 & \\
\hline 14 & 2 & 0 & 1 & 1 & 0 & One state official said \\
\hline 15 & 8 & 0 & 0 & 0 & 0 & \\
\hline 16 & 9 & 0 & 0 & 0 & 0 & \\
\hline 17 & 2 & 0 & 0 & 0 & 0 & \\
\hline 18 & 6 & 0 & 0 & 0 & 0 & \\
\hline 19 & 4 & 0 & 1 & 1 & 0 & Pollsters said \\
\hline 20 & 3 & 0 & 0 & 0 & 0 & \\
\hline 21 & 4 & 0 & 0 & 0 & 0 & \\
\hline 22 & 6 & 0 & 0 & 0 & 0 & \\
\hline \multirow[t]{2}{*}{23} & 7 & 0 & 1 & 1 & 0 & MSHA'S \\
\hline & & & & & & lead investigator said \\
\hline 24 & 5 & 0 & 0 & 0 & 0 & \\
\hline 25 & 2 & 0 & 0 & 0 & 0 & \\
\hline 26 & 1 & 1 & 0 & 1 & 0 & A person confirmed \\
\hline \multirow[t]{2}{*}{27} & 5 & 0 & 1 & 1 & 0 & National Political \\
\hline & & & & & & Pundits repeatedly report \\
\hline 28 & 2 & 0 & 0 & 0 & 0 & \\
\hline \multirow[t]{2}{*}{29} & 12 & 0 & 2 & 2 & 0 & Coal industry officials said, \\
\hline & & & & & & Environmentalists said \\
\hline 30 & 5 & 0 & 0 & 0 & 0 & \\
\hline 31 & 1 & 0 & 0 & 0 & 0 & \\
\hline 32 & 5 & 0 & 1 & 1 & 0 & Bush officials say \\
\hline 33 & 7 & 0 & 0 & 0 & 0 & \\
\hline 34 & 7 & 0 & 0 & 0 & 0 & \\
\hline 35 & 3 & 0 & 0 & 0 & 0 & \\
\hline 36 & 1 & 1 & 0 & 2 & 0 & Critics say \\
\hline 37 & 3 & 0 & 0 & 0 & 0 & \\
\hline 38 & 6 & 0 & 1 & 1 & 0 & Campaign officials said \\
\hline 39 & 7 & 0 & 0 & 0 & 0 & \\
\hline
\end{tabular}




\begin{tabular}{|c|c|c|c|c|c|c|}
\hline 40 & 3 & 0 & 0 & 0 & 0 & \\
\hline 41 & 8 & 0 & 0 & 0 & 0 & \\
\hline 42 & 2 & 0 & 0 & 0 & 0 & \\
\hline 43 & 15 & 0 & 1 & 1 & 0 & Local activists say \\
\hline 44 & 1 & 0 & 0 & 0 & 0 & \\
\hline 45 & 7 & 0 & 0 & 0 & 0 & \\
\hline 46 & 4 & 0 & 0 & 0 & 0 & \\
\hline 47 & 1 & 0 & 0 & 0 & 0 & \\
\hline 48 & 6 & 0 & 0 & 0 & 0 & \\
\hline 49 & 7 & 0 & 0 & 0 & 0 & \\
\hline 50 & 18 & 0 & 1 & 1 & 0 & Campaign officials point \\
\hline 51 & 2 & 0 & 1 & 1 & 0 & Agency officials said \\
\hline 52 & 4 & 0 & 0 & 0 & 0 & \\
\hline 53 & 18 & 0 & 1 & 0 & 1 & $\begin{array}{c}\text { Consumer Union analysts } \\
\text { warn }\end{array}$ \\
\hline 54 & 2 & 0 & 0 & 0 & 0 & \\
\hline 55 & 2 & 0 & 0 & 0 & 0 & \\
\hline 56 & 4 & 0 & 0 & 0 & 0 & \\
\hline 57 & 4 & 0 & 0 & 0 & 0 & \\
\hline 58 & 4 & 0 & 0 & 0 & 0 & \\
\hline 59 & 4 & 0 & 1 & 1 & 0 & head of a group told \\
\hline 60 & 3 & 0 & 0 & 0 & 0 & \\
\hline 61 & 3 & 0 & 0 & 0 & 0 & \\
\hline \multirow[t]{2}{*}{62} & 7 & 0 & 1 & 1 & 0 & Some conservative \\
\hline & & & & & & leaders have criticized Bush \\
\hline 63 & 3 & 0 & 0 & 0 & 0 & \\
\hline 64 & 2 & 0 & 0 & 0 & 0 & \\
\hline 65 & 2 & 0 & 0 & 0 & 0 & \\
\hline 66 & 3 & 0 & 0 & 0 & 0 & \\
\hline 67 & 4 & 0 & 0 & 0 & 0 & \\
\hline 68 & 10 & 0 & 0 & 0 & 0 & \\
\hline 69 & 3 & 0 & 0 & 0 & 0 & \\
\hline 70 & 5 & 0 & 1 & 1 & 0 & $\begin{array}{c}\text { Industry officials are } \\
\text { optimistic }\end{array}$ \\
\hline 71 & 7 & 0 & 0 & 0 & 0 & \\
\hline \multirow[t]{2}{*}{72} & 5 & 0 & 1 & 1 & 0 & Some Kerry \\
\hline & & & & & & supporters questioned \\
\hline 73 & 12 & 0 & 1 & 2 & 0 & The superintendent said \\
\hline 74 & 9 & 0 & 0 & 0 & 0 & \\
\hline \multirow[t]{2}{*}{75} & 6 & 0 & 1 & 1 & 0 & A group financed \\
\hline & & & & & & by trial lawyers supported \\
\hline 76 & 4 & 0 & 0 & 0 & 0 & \\
\hline \multirow[t]{2}{*}{77} & 11 & 0 & 2 & 2 & 0 & Critics say, \\
\hline & & & & & & A study by an economist \\
\hline 78 & 6 & 0 & 0 & 0 & 0 & \\
\hline 79 & 6 & 0 & 1 & 1 & 0 & Company officials say \\
\hline 80 & 2 & 0 & 0 & 0 & 0 & \\
\hline 81 & 2 & 0 & 0 & 0 & 0 & \\
\hline Total & 408 & 4 & 24 & 30 & 1 & \\
\hline
\end{tabular}


Type- Traditional Journalism, Paper- Dayton Daily News

\begin{tabular}{|c|c|c|c|c|c|c|}
\hline Article & Known & Anonymous & Anonymous & Anonymous & Anonymous & Anonymous \\
\hline Number & Sources & Sources & Sources & Attributions & Quotes & Source used \\
\hline & & & $\begin{array}{c}\text { (with } \\
\text { Identifier) }\end{array}$ & (Paraphrases) & & \\
\hline & & & & & & \\
\hline 1 & 15 & 0 & 0 & 0 & 0 & \\
\hline 2 & 6 & 0 & 0 & 0 & 0 & \\
\hline 3 & 5 & 0 & 1 & 1 & 0 & A spokeswoman said \\
\hline 4 & 5 & 0 & 0 & 0 & 0 & \\
\hline 5 & 10 & 0 & 0 & 0 & 0 & \\
\hline 6 & 3 & 0 & 0 & 0 & 0 & \\
\hline 7 & 2 & 0 & 0 & 0 & 0 & \\
\hline 8 & 6 & 0 & 0 & 0 & 0 & \\
\hline 9 & 6 & 0 & 0 & 0 & 0 & \\
\hline 10 & 8 & 0 & 0 & 0 & 0 & \\
\hline 11 & 1 & 0 & 0 & 0 & 0 & \\
\hline 12 & 4 & 0 & 0 & 0 & 0 & \\
\hline 13 & 5 & 0 & 0 & 0 & 0 & \\
\hline 14 & 4 & 0 & 0 & 0 & 0 & \\
\hline 15 & 0 & 0 & 2 & 1 & 1 & Spokesman said \\
\hline 16 & 1 & 0 & 1 & 1 & 0 & An organizer said \\
\hline 17 & 6 & 0 & 0 & 0 & 0 & \\
\hline 18 & 2 & 0 & 0 & 0 & 0 & \\
\hline 19 & 2 & 0 & 0 & 0 & 0 & \\
\hline 20 & 10 & 0 & 0 & 0 & 0 & \\
\hline 21 & 1 & 0 & 0 & 0 & 0 & \\
\hline 22 & 3 & 0 & 1 & 0 & 1 & one VFW member said \\
\hline 23 & 6 & 0 & 0 & 0 & 0 & \\
\hline 24 & 3 & 0 & 0 & 0 & 0 & \\
\hline 25 & 7 & 0 & 0 & 0 & 0 & \\
\hline 26 & 1 & 0 & 0 & 0 & 0 & \\
\hline 27 & 4 & 0 & 0 & 0 & 0 & \\
\hline 28 & 6 & 0 & 0 & 0 & 0 & \\
\hline 29 & 7 & 0 & 0 & 0 & 0 & \\
\hline 30 & 3 & 0 & 0 & 0 & 0 & \\
\hline 31 & 6 & 0 & 0 & 0 & 0 & \\
\hline 32 & 4 & 0 & 0 & 0 & 0 & \\
\hline 33 & 5 & 0 & 1 & 1 & 0 & Organizers said \\
\hline 34 & 4 & 0 & 0 & 0 & 0 & \\
\hline 35 & 8 & 0 & 0 & 0 & 0 & \\
\hline 36 & 6 & 0 & 1 & 1 & 0 & A Kerry spokesman said \\
\hline 37 & 6 & 0 & 0 & 0 & 0 & \\
\hline 38 & 9 & 0 & 0 & 0 & 0 & \\
\hline 39 & 14 & 0 & 0 & 0 & 0 & \\
\hline 40 & 3 & 0 & 0 & 0 & 0 & \\
\hline 41 & 5 & 0 & 0 & 0 & 0 & \\
\hline 42 & 4 & 0 & 0 & 0 & 0 & \\
\hline
\end{tabular}




\begin{tabular}{|c|c|c|c|c|c|c|}
\hline 43 & 7 & 0 & 0 & 0 & 0 & \\
\hline 44 & 6 & 0 & 0 & 0 & 0 & \\
\hline 45 & 8 & 0 & 0 & 0 & 0 & \\
\hline 46 & 3 & 0 & 0 & 0 & 0 & \\
\hline 47 & 3 & 0 & 0 & 0 & 0 & \\
\hline 48 & 6 & 0 & 0 & 0 & 0 & \\
\hline 49 & 3 & 0 & 0 & 0 & 0 & \\
\hline 50 & 12 & 0 & 0 & 0 & 0 & \\
\hline 51 & 6 & 0 & 0 & 0 & 0 & \\
\hline 52 & 1 & 0 & 0 & 0 & 0 & \\
\hline 53 & 4 & 0 & 0 & 0 & 0 & \\
\hline 54 & 6 & 0 & 0 & 0 & 0 & \\
\hline 55 & 1 & 0 & 0 & 0 & 0 & \\
\hline 56 & 8 & 0 & 0 & 0 & 0 & \\
\hline 57 & 10 & 0 & 0 & 0 & 0 & \\
\hline 58 & 6 & 0 & 1 & 1 & 0 & $\begin{array}{c}\text { The leader of the group } \\
\text { said }\end{array}$ \\
\hline 59 & 6 & 0 & 0 & 0 & 0 & \\
\hline 60 & 6 & 0 & 0 & 0 & 0 & \\
\hline \multirow[t]{3}{*}{61} & 15 & 2 & 2 & 4 & 0 & analysts estimate, \\
\hline & & & & & & proponents say, \\
\hline & & & & & & advocates say \\
\hline 62 & 6 & 0 & 0 & 0 & 0 & \\
\hline 63 & 2 & 0 & 1 & 1 & 0 & Campaign officials said \\
\hline 64 & 8 & 0 & 0 & 0 & 0 & \\
\hline 65 & 9 & 0 & 0 & 0 & 0 & \\
\hline 66 & 3 & 0 & 0 & 0 & 0 & \\
\hline \multirow[t]{2}{*}{67} & 10 & 0 & 2 & 2 & 0 & Bush officials say, \\
\hline & & & & & & Kerry supporters note \\
\hline 68 & 5 & 0 & 0 & 0 & 0 & \\
\hline 69 & 6 & 0 & 0 & 0 & 0 & \\
\hline 70 & 5 & 0 & 1 & 1 & 0 & A Bush spokesman said \\
\hline 71 & 5 & 0 & 0 & 0 & 0 & \\
\hline 72 & 7 & 0 & 0 & 0 & 0 & \\
\hline 73 & 7 & 0 & 0 & 0 & 0 & \\
\hline 74 & 5 & 0 & 0 & 0 & 0 & \\
\hline 75 & 9 & 0 & 1 & 1 & 0 & Organizers said \\
\hline 76 & 5 & 0 & 0 & 0 & 0 & \\
\hline 77 & 3 & 0 & 0 & 0 & 0 & \\
\hline \multirow[t]{2}{*}{78} & 4 & 0 & 2 & 2 & 0 & $\begin{array}{l}\text { A District Court judge } \\
\text { said, }\end{array}$ \\
\hline & & & & & & Local boards promised \\
\hline Total & 432 & 2 & 17 & 17 & 2 & \\
\hline
\end{tabular}

